\title{
In vitro antileishmanial activity of Anacardium othonianum and isolated compounds against Leishmania amazonensis
}

\author{
Tavane Aparecida Alvarengaa®, Osvaine Junior Alvarenga Alvesa®, Mariana Cintra Pagottia®, \\ Wilson Roberto Cunhab®, Márcio Luís Andrade e Silvab®, Juliana de Fátima Salesc®, Fabiano \\ Guimarães Silvac®, Ana Helena Januariob®, Lizandra Guidi Magalhães ${ }^{\natural} \bullet$, Patrícia Mendonça \\ Paulettia ${ }^{*} \bullet$ \\ a Programa de Pós-graduação em Ciências, Universidade de Franca, Franca, 14404-600, São Paulo, Brasil. \\ * patricia.pauletti@unifran.edu.br \\ b Universidade de Franca, Franca, 14404-600, São Paulo, Brasil. \\ * patricia.pauletti@unifran.edu.br \\ c Instituto Federal de Educação, Ciência e Tecnologia Goiano, Rio Verde, Rio Verde, 75901-970, Goiás, Brasil.
}

Received: July 20, 2020 / Accepted: October 27, 2020/ Published online: January 27, 2021

\begin{abstract}
This study analyzes the antileishmanial activity of the crude ethanol extract, fractions, and isolated compounds of $A$. othonianum nuts. Antileishmanial activity was evaluated against Leishmania amazonensis promastigotes in vitro. The phytochemical study was performed by high-performance liquid chromatography-high-resolution mass spectrometry-diode array detector (HPLC-HRMS-DAD) and by preparative HPLC. HPLC-HRMS-DAD analysis of the bioactive extract confirmed the presence of ten alkyl phenol derivatives that had previously been isolated from A. occidentale. Bioassay-guided isolation afforded cardanol triene, cardanol diene, cardanol monoene, cardol triene, anacardic acid triene, anacardic acid diene, and anacardic acid monoene. Cardol triene gave an $\mathrm{IC}_{50}$ of $80.66 \mu \mathrm{M}$. The obtained data suggest that the evaluated extract, fractions, and cardol triene had moderate activity against L. amazonensis promastigotes. This is the first description of alkyl phenols in A. othonianum.
\end{abstract}

Keywords: Alkyl phenols, Anacardiaceae, anacardic acid, cardol.

\section{Atividade antileishmania in vitro de Anacardium othonianum e substâncias isoladas em Leishmania amazonensis}

\begin{abstract}
Resumo
Este estudo visou avaliar a atividade antileishmanial do extrato bruto etanólico, frações e substâncias isoladas obtidos das castanhas de A. othonianum. A atividade antileishmania foi avaliada por ensaio in vitro nas formas promastigotas de Leishmania amazonensis. O estudo fitoquímico foi realizado por cromatografia líquida de alta eficiência - espectrometria de massa de alta resolução - detector de arranjo de diodos (CLAE-EMAR-DAD) e por CLAE-preparativa. A análise por CLAE-EMAR-DAD do extrato bioativo confirmou a presença de dez derivados de alquil-fenóis previamente isolados de A. occidentale. A investigação bioguiada resultou no isolamento do cardanol trieno, cardanol dieno, cardanol monoeno, cardol trieno, ácido anacárdico trieno, ácido anacárico dieno e ácido anacárico monoeno. O cardol trieno apresentou uma $\mathrm{CI}_{50}$ de $80,66 \mu \mathrm{M}$. Os dados obtidos sugeriram que o extrato, frações e o cardol trieno possuem atividade moderada no ensaio nas formas promastigotas de L. amazonensis. Este é o primeiro relato de alquil-fenóis em A. othonianum.
\end{abstract}

Palavras-chave: alquil-fenóis, Anacardiaceae, ácido anacárdico, cardol.

Anacardium othonianum (Rizz.) (Anacardiaceae) is a native species of the Brazilian Cerrado. This species produces cashew fruit, which is popularly known as "caju-do-cerrado", "cajuzinho", and "cajuí". A. othonianum has regional importance: its pseudofruit is consumed fresh or in juices, liqueurs, and sweets, and its fruit (cashew nuts) is consumed after being roasted with salt (Souza \& Silva, 2015). In 44 traditional medicine, A. othonianum is used to treat infections, inflammations, respiratory pathologies (cough and flu), diabetes, and pain (Bessa et al., 2013).

The crude ethanol extract of $A$. othonianum leaves presents antifungal activity. In addition, the isolated compounds amentoflavone, gallic acid, protocatechuic acid, and ethyl 3,4,5-trimethoxybenzoate have been isolated and 
also shown to display antifungal activity (Curado et al., 2016). Nevertheless, the crude extract obtained from A. othonianum nuts has not yet been investigated.

A. occidentale $\mathrm{L}$. nuts are known to be a source of alkyl phenols, which exhibit several biological activities. These phenols inhibit Trypanosoma cruzi sirtuin and exert anti-T. cruzi (Matutino Bastos et al., 2019), antiplasmodial (Gimenez et al., 2019), schistosomicidal (Alvarenga et al., 2016), and molluscicidal activity (Kubo, Komatsu \& Ochi, 1986), among other activities.

Protozoan parasites of the genus Leishmania are the etiological agent of the disease leishmaniasis, which affects the skin, mucous membranes, and internal organs. Between 700,000 and 1 million new cases of leishmaniasis are estimated to emerge annually (WHO, 2020). This disease affects poor regions in Africa, Asia, and Latin America (WHO, 2020). The treatment of leishmaniasis consists of the use of antimonials, amphotericin B, pentamidine, paromomycin, and miltefosine. However, these drugs are costly, difficult to administer, and highly toxic, not to mention the emerging resistance to them (Ghorbani \& Farhoudi, 2018; Hendrickx, Caljon \& Maes, 2019; Charlton, Rossi-Bergmann, Denny \& Steel, 2018).

As part of our ongoing research into Anacardium (Alvarenga et al., 2016; Curado et al., 2016; Gazzola et al., 2017; Gimenez et al., 2019), and because the crude extract of Anacardium othonianum (Rizz.) (Anacardiaceae) nuts has been demonstrated to display antileishmanial activity in vitro (Alvarenga, 2020), this study analyzes the antileishmanial activity of the crude ethanol extract, fractions, and isolated compounds of $A$. othonianum nuts.

Analytical HPLC data were obtained on a Shimadzu LC20AD chromatograph (Kyoto, Japan) equipped with a DAD detector (SPD-M20A), an automatic injector (SIL-20A-HT), and an oven (CTO-20A). Preparative HPLC purification steps were run on a Shimadzu LC-6AD chromatograph (Kyoto, Japan) equipped with a UV-Vis detector (SPD-20A). HPLC columns were as follows: Shimadzu Shim-pack ODS columns $(5 \mu \mathrm{m}, 250 \times 4.60 \mathrm{~mm}$, and $250 \times 20 \mathrm{~mm})$ and Phenomenex Luna ODS column $(5 \mu \mathrm{m}, 250 \times 4.60 \mathrm{~mm})$. TLC analyses were performed on Sigma-Aldrich silica gel plates on aluminum foil with fluorescence indicator. Octadecyl silica (ODS) and silica gel 60 (Sigma-Aldrich) were used as chromatographic support.

The Nuclear Magnetic Resonance data of the compounds dissolved in $\mathrm{CDCl}_{3}$ (Sigma-Aldrich) were acquired on Bruker Avance DRX 400 and 500 spectrometers (Billerica, MA, USA). The HPLC-HRMS-DAD data of the crude ethanol extract of cashew nuts were obtained on an LC-20AD HPLC (Shimadzu, Kyoto, Japan) and micrOTOF-QII ESI mass spectrometer (Bruker Daltonics, Billerica, MA, USA). The same parameters described by Bertanha et al. (2020) were applied. An ODS column (Phenomenex) was employed. The mobile phase consisted of 70:30 acetonitrile/water $(+0.2 \%$ formic acid) for $60 \mathrm{~min}$, followed by a linear gradient from 70 to $100 \%$ acetonitrile for $10 \mathrm{~min}$, and $100 \%$ acetonitrile for 10 $\mathrm{min}$. The flow rate was $1.0 \mathrm{~mL} / \mathrm{min}$.

The fruits of species Anacardium othonianum Riss. (Anacardiaceae) were provided by Prof. Dr. Fabiano Silva. A voucher specimen (HJ3793) was deposited in the Herbarium Jataiense Germano Guarim Neto of the Federal University of
Goiás, Brazil (Herbarium HJ). The license to access genetic heritage was SisGen \#AC7C911.

The air-dried powdered nuts $(62.3 \mathrm{~g})$ were extracted with ethanol (Alvarenga et al., 2016). After filtration, the solvent was removed under reduced pressure to yield $14.3 \mathrm{~g}$ of the extract. The crude ethanol extract (CEE, 7.0 g) was submitted to solid-phase extraction on octadecyl silica (ODS); methanol/water (80:20, 90:10, and 100:0 v/v) was used as mobile phase. This procedure yielded three fractions (FR1, methanol/water 80:20, $4.24 \mathrm{~g}$; FR2, methanol/water 90:10, $2.26 \mathrm{~g}$; and FR3, methanol, $0.40 \mathrm{~g}$ ). Fraction 1, which was eluted with methanol/water 80:20 (v/v, 4.2 g), was fractionated by chromatography on silica; hexane/EtOAc (ethyl acetate) was the mobile phase, yielding two hundred and thirty-two subfractions of $10 \mathrm{~mL}$, which were combined in twenty-six subfractions by using TLC data. Subfractions 12-20 (75 mg) were submitted to preparative RP-HPLC purification with acetonitrile/water $(98: 2, \mathrm{v} / \mathrm{v})$, with UV detection at $220 \mathrm{~nm}$ and flow rate of $5 \mathrm{~mL} / \mathrm{min}$, which afforded eight subfractions. Subfractions 3, 5, and 7 gave compounds 1 ( $\left.3.5 \mathrm{mg}, \mathrm{t}_{\mathrm{R}} 22.9 \mathrm{~min}\right), 2\left(1.7 \mathrm{mg}, \mathrm{t}_{\mathrm{R}} 28.2 \mathrm{~min}\right)$, and $\mathbf{3}\left(3.4 \mathrm{mg}, \mathrm{t}_{\mathrm{R}} 37.5 \mathrm{~min}\right)$, respectively. Subfractions $30-85$ $(1.3 \mathrm{~g})$ were chromatographed on octadecyl silica (ODS), and an acetonitrile/water gradient was employed as mobile phase. Subfraction 2 gave compound 4 (193.9 $\mathrm{mg})$.

Subfractions $172-220 \quad(318 \quad \mathrm{mg})$ were also chromatographed by preparative RP-HPLC with acetonitrile/water $(99: 1, \mathrm{v} / \mathrm{v})$, with UV detection at $220 \mathrm{~nm}$ and flow rate of $5 \mathrm{~mL} / \mathrm{min}$, yielding four fractions. These procedures led to the isolation of compounds $5\left(71.0 \mathrm{mg}, \mathrm{t}_{\mathrm{R}}\right.$ $22.0 \mathrm{~min}), 6\left(18.1 \mathrm{mg}, \mathrm{t}_{\mathrm{R}} 27.7 \mathrm{~min}\right)$, and $7\left(12.0 \mathrm{mg}, \mathrm{t}_{\mathrm{R}} 37.2\right.$ $\min )$.

The extract, fractions, and compounds were evaluated against Leishmania amazonensis (MHOM/BR/PH8) promastigotes $\left(1 \times 10^{6}\right.$ parasites per well) according to a previous reference (Andrade et al., 2018). The extract and fractions were tested at $50 \mu \mathrm{g} / \mathrm{mL}$; compounds were tested at $100,80,50,25$, and $12.5 \mu \mathrm{M}$. Amphotericin B was used as positive control; the negative control was RPMI 1640 medium containing $0.1 \%$ DMSO. The $\mathrm{IC}_{50}(50 \% \mathrm{~L}$. amazonensis promastigote flagellar motility inhibition) was obtained by using GraphPad Prism 6 .

The crude ethanol extract (CEE) inhibited $96.00 \% \pm$ $1.47 \%$ of the Leishmania amazonensis promastigote flagellar motility. The CEE was purified by solid-phase extraction, which yielded three fractions. Fractions 1 (FR1) and 3 (FR3) inhibited flagellar motility the most effectively, by $86.48 \pm$ 0.95 and $83.54 \pm 1.15 \%$, respectively, in comparison with Fraction $2(\mathrm{FR} 2=50.47 \pm 2.52 \%)$. Thus, activity was maintained after CEE fractionation.

The CEE chromatogram was obtained between 200 and $800 \mathrm{~nm}$, and in the negative mode. High-resolution mass spectra provided the exact mass for the obtained peaks and was employed to calculate the molecular formulae and errors (Table 1). The molecular formulae already described in the literature (Correia, David \& David, 2006) for compounds from the genus Anacardium were compared with the molecular formulae obtained in this study. Thus, CEE analysis by HPLC-HRMS-DAD revealed the presence of ten 
known alkyl phenols, namely cardol triene, cardol diene, anacardic acid triene, cardanol triene, anacardic acid diene, cardanol diene, anacardic acid monoene, cardanol monoene, anacardic acid, and cardanol. This indicates that $A$. othonianum is also a rich source of these compounds.

Table 1. HPLC-HRMS data for the compounds identified in the crude ethanol extract (CEE) obtained from A. othonianum.

\begin{tabular}{|c|c|c|c|c|c|}
\hline $\begin{array}{c}t_{R} \\
(\mathrm{~min}) \\
\end{array}$ & $m / z$ & Ion & $\begin{array}{l}\text { Molecular } \\
\text { formula }\end{array}$ & $\begin{array}{c}\text { Tentative } \\
\text { Identification }\end{array}$ & $\begin{array}{l}\text { Error } \\
(\mathrm{ppm})\end{array}$ \\
\hline \multirow[t]{2}{*}{19.8} & 313.2173 & {$[\mathrm{M}-\mathrm{H}]^{-}$} & $\mathrm{C}_{21} \mathrm{H}_{29} \mathrm{O}_{2}$ & Cardol triene & -0.0 \\
\hline & 627.4416 & {$[2 \mathrm{M}-\mathrm{H}]$} & $\mathrm{C}_{42} \mathrm{H}_{59} \mathrm{O}_{4}$ & Cardol triene & -0.28 \\
\hline \multirow[t]{2}{*}{28.7} & 315.2316 & {$[\mathrm{M}-\mathrm{H}]^{-}$} & $\mathrm{C}_{21} \mathrm{H}_{31} \mathrm{O}_{2}$ & Cardol diene & -1.35 \\
\hline & 631.4713 & {$[2 \mathrm{M}-\mathrm{H}]^{-}$} & $\mathrm{C}_{42} \mathrm{H}_{63} \mathrm{O}_{4}$ & Cardol triene & -1.88 \\
\hline \multirow[t]{3}{*}{45.5} & 341.2137 & {$[\mathrm{M}-\mathrm{H}]^{-}$} & $\mathrm{C}_{22} \mathrm{H}_{29} \mathrm{O}_{3}$ & $\begin{array}{c}\text { Anacardic acid } \\
\text { triene }\end{array}$ & 1.48 \\
\hline & 683.4310 & {$[2 \mathrm{M}-\mathrm{H}]^{-}$} & $\mathrm{C}_{44} \mathrm{H}_{59} \mathrm{O}_{6}$ & $\begin{array}{c}\text { Anacardic acid } \\
\text { triene }\end{array}$ & -0.71 \\
\hline & 297.2220 & {$[\mathrm{M}-\mathrm{H}]^{-}$} & $\mathrm{C}_{21} \mathrm{H}_{29} \mathrm{O}$ & Cardanol triene & -0.39 \\
\hline \multirow[t]{3}{*}{66.4} & 343.2280 & {$[\mathrm{M}-\mathrm{H}]^{-}$} & $\mathrm{C}_{22} \mathrm{H}_{31} \mathrm{O}_{3}$ & $\begin{array}{c}\text { Anacardic acid } \\
\text { diene }\end{array}$ & 0.13 \\
\hline & 687.4600 & {$[2 \mathrm{M}-\mathrm{H}]^{-}$} & $\mathrm{C}_{44} \mathrm{H}_{63} \mathrm{O}_{6}$ & $\begin{array}{l}\text { Anacardic acid } \\
\text { triene }\end{array}$ & -3.01 \\
\hline & 299.2374 & {$[\mathrm{M}-\mathrm{H}]^{-}$} & $\mathrm{C}_{21} \mathrm{H}_{31} \mathrm{O}$ & Cardanol diene & -0.64 \\
\hline \multirow[t]{2}{*}{68.5} & 343.2267 & {$[\mathrm{M}-\mathrm{H}]^{-}$} & $\mathrm{C}_{22} \mathrm{H}_{31} \mathrm{O}_{3}$ & n.i. & -1.17 \\
\hline & 299.2372 & {$[\mathrm{M}-\mathrm{H}]^{-}$} & $\mathrm{C}_{21} \mathrm{H}_{31} \mathrm{O}$ & n.i. & -0.84 \\
\hline 69.3 & 331.2265 & {$[\mathrm{M}-\mathrm{H}]^{-}$} & $\mathrm{C}_{21} \mathrm{H}_{31} \mathrm{O}_{3}$ & n.i. & -1.37 \\
\hline \multirow[t]{2}{*}{70.6} & 369.2425 & {$[\mathrm{M}-\mathrm{H}]^{-}$} & $\mathrm{C}_{24} \mathrm{H}_{33} \mathrm{O}_{3}$ & n.i. & -1.02 \\
\hline & 325.2517 & {$[\mathrm{M}-\mathrm{H}]^{-}$} & $\mathrm{C}_{23} \mathrm{H}_{33} \mathrm{O}$ & n.i. & -1.99 \\
\hline 71.3 & 369.2422 & {$[\mathrm{M}-\mathrm{H}]^{-}$} & $\mathrm{C}_{24} \mathrm{H}_{33} \mathrm{O}_{3}$ & n.i. & -1.32 \\
\hline 71.7 & 387.2523 & {$[\mathrm{M}-\mathrm{H}]^{-}$} & $\mathrm{C}_{24} \mathrm{H}_{35} \mathrm{O}_{4}$ & n.i. & -1.78 \\
\hline \multirow[t]{2}{*}{72.2} & 319.2265 & {$[\mathrm{M}-\mathrm{H}]^{-}$} & $\mathrm{C}_{20} \mathrm{H}_{31} \mathrm{O}_{3}$ & n.i. & -1.37 \\
\hline & 275.2371 & {$[\mathrm{M}-\mathrm{H}]^{-}$} & $\mathrm{C}_{19} \mathrm{H}_{31} \mathrm{O}$ & n.i. & -0.94 \\
\hline \multirow[t]{2}{*}{73.8} & 345.2419 & {$[\mathrm{M}-\mathrm{H}]^{-}$} & $\mathrm{C}_{22} \mathrm{H}_{33} \mathrm{O}_{3}$ & $\begin{array}{c}\text { Anacardic acid } \\
\text { monoene }\end{array}$ & -1.62 \\
\hline & 301.2527 & {$[\mathrm{M}-\mathrm{H}]^{-}$} & $\mathrm{C}_{21} \mathrm{H}_{33} \mathrm{O}$ & $\begin{array}{l}\text { Cardanol } \\
\text { monoene }\end{array}$ & -0.99 \\
\hline \multirow[t]{3}{*}{79.0} & 347.2580 & {$[\mathrm{M}-\mathrm{H}]^{-}$} & $\mathrm{C}_{22} \mathrm{H}_{35} \mathrm{O}_{3}$ & Anacardic acid & -1.17 \\
\hline & 373.2726 & {$[\mathrm{M}-\mathrm{H}]^{-}$} & $\mathrm{C}_{24} \mathrm{H}_{37} \mathrm{O}_{3}$ & n.i. & -2.22 \\
\hline & 303.2689 & {$[\mathrm{M}-\mathrm{H}]^{-}$} & $\mathrm{C}_{21} \mathrm{H}_{35} \mathrm{O}$ & Cardanol & -0.44 \\
\hline
\end{tabular}

n.i. not identified

FR1 had higher yield and was purified by various chromatographic purification steps to give the main compounds (Figure 1): cardanol triene (1), cardanol diene (2), cardanol monoene (3), cardol triene (4), anacardic acid triene (5), anacardic acid diene (6), and anacardic acid monoene (7). These compounds were identified by NMR and by comparison with previously published data (Alvarenga et al., 2016; Lomonaco et al., 2012).

Compound 4 displayed leishmanicidal activity. Its $\mathrm{IC}_{50}$ was $80.66 \mu \mathrm{M}$ (95\% confidence interval [CI], 80.44 to $80.87 \mu \mathrm{M})$. Compounds $1-3$ and 5-7 provided $\mathrm{IC}_{50}>100 \mu \mathrm{M}$. These data suggest that the presence of an extra hydroxyl group at the aromatic ring as well as the absence of the acid group improved the activity of compound 4 in relation to compounds 1 and 5 , which also presented three double bonds at the $\mathrm{C}_{15}$ carbon chain.

According to previously published data (Alvarenga et al., 2016), cardol diene and 2-methyl cardol diene present schistosomicidal activity against Schistosoma mansoni adult worms, with $\mathrm{LC}_{50}$ of 32.2 and $14.5 \mu \mathrm{M}$, respectively.
Additionally, these compounds are active against Plasmodium falciparum D6 strain, with $\mathrm{IC}_{50}$ of 5.69 and 5.39 $\mu \mathrm{M}$, respectively (Gimenez et al., 2019). Cardol triene has higher activity against trypomastigote and amastigote forms of $T$. cruzi, with $\mathrm{EC}_{50}$ of $23.36 \pm 0.12$ and $11.75 \pm 0.40 \mu \mathrm{M}$, respectively, in comparison to cardanol triene and anacardic acid triene (Matutino Basto et al., 2019). Mixtures of anacardic acid, cardol, and cardanol display good larvicidal action against Aedes aegypti, with $\mathrm{LC}_{50}$ of $12.40 \pm 0.10 \mathrm{ppm}$, $5.55 \pm 0.07 \mathrm{ppm}$, and $8.20 \pm 0.15 \mathrm{ppm}$, respectively (Oliveira et al., 2011). For Biomphalaria glabrata, the snail vector of schistosomiasis, evaluations showed that anacardic acid triene is the most active molluscicidal agent $\left(\mathrm{LD}_{50}=0.3\right.$ $\mathrm{ppm}$ ), followed by cardol triene $\left(\mathrm{LD}_{50}=15 \mathrm{ppm}\right)$, with cardanol triene being the least active agent $\left(\mathrm{LD}_{50}=80 \mathrm{ppm}\right)$ (Kubo et al., 1986).

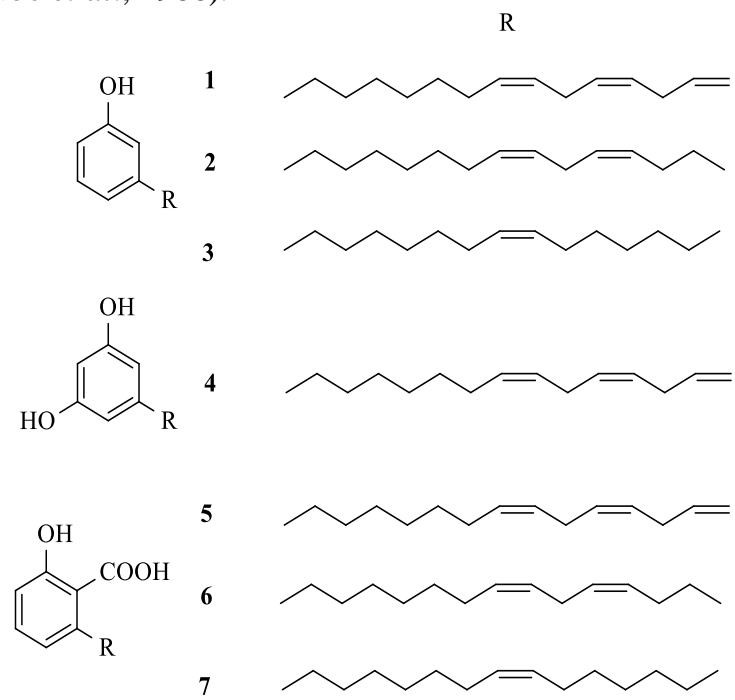

Figure 1. Chemical structure of the isolated compounds.

Anacardium othonianum extract, fractions, and cardol triene can moderately inhibit L. amazonensis promastigote flagellar motility. Additionally, the occurrence of alkyl phenols in A. othonianum has been confirmed for the first time. Nevertheless, further in vivo studies are important to evaluate the leishmanicidal potential of the Anacardium othonianum extract, fractions, and compounds.

\section{Acknowledgements}

The National Council for Scientific and Technological Development (CNPq), the Coordination for the Improvement of Higher Education Personnel (CAPES, Finance Code 001), and the São Paulo Research Foundation - FAPESP (grant number 2017/24860-0) are acknowledged for fellowships. This research was supported by the São Paulo Research Foundation (grant number 2016/10313-4).

\section{References}

Alvarenga, T. A. (2020). Estudo fitoquímico e avaliação da atividade leishmanicida de Anacardium othonianum Riss. (Tese de doutorado). Universidade de Franca, Franca, São Paulo.

Alvarenga, T. A., de Oliveira, P. F., de Souza, J. M., Tavares, D. C., Andrade E Silva, M. L., Cunha, W. R., Groppo, M., Januário, A. H., Magalhães, L. G. \& Pauletti, P. M. (2016). Schistosomicidal activity of alkyl- 
phenols from the cashew Anacardium occidentale against Schistosoma mansoni adult worms. Journal of Agricultural and Food Chemitry, 64(46), 8821-8827. doi: 10.1021/acs.jafc.6b04200

Andrade, P. M., Melo, D. C., Alcoba, A. E. T., Ferreira Júnior, W. G., Pagotti, M. C., Magalhães, L. G., Santos, T. C. L. D., Crotti, A. E. M., Alves, C. C. F. \& Miranda, M. L. D. (2018). Chemical composition and evaluation of antileishmanial and cytotoxic activities of the essential oil from leaves of Cryptocarya aschersoniana Mez. (Lauraceae Juss.). Anais da Academia Brasileira de Ciências, 90(3), 2671-2678. doi: 10.1590/00013765201820170332

Bertanha, C. S., Gimenez, V. M. M., Furtado, R. A., Tavares, D. C., Cunha, W. R., Silva, M. L. A., Januário, A. H., Borges, A., Kawano, D. F., Parreira, R. L. T. \& Pauletti, P. M. (2020). Isolation, in vitro and in silico evaluation of phenylethanoid glycoside from Arrabidaea brachypoda as lipoxygenase inhibitor. Journal of the Brazilian Chemical Society, 31(4), 849-855. doi: 10.21577/0103-5053.20190248

Bessa, N. G. F. de, Borges, J. C. M., Beserra, F. P, Carvalho, R. H. A., Pereira, M. A. B., Fagundes, R., Campos, S. L., Ribeiro, L. U, Quirino, M. S, Chagas Junior, A. F \& Alves, A. (2013). Prospecção fitoquímica preliminar de plantas nativas do cerrado de uso popular medicinal pela comunidade rural do assentamento vale verde - Tocantins. Revista Brasileira de Plantas Medicinais, 15(4), 692-707. doi: 10.1590/S151605722013000500010

Charlton, R. L., Rossi-Bergmann, B., Denny, P. W. \& Steel, P. G. (2018). Repurposing as a strategy for the discovery of new anti-leishmanials: thestate-of-the-art. Parasitology, 145(2), 219-236. doi: 10.1017/S0031182017000993

Correia, S. de J., David, J. P., David J. M. (2006). Metabólitos secundários de espécies de Anacardiaceae. Química Nova,29(6), 1287-1300. doi: 10.1590/S0100-40422006000600026

Curado, F. M. L. M. J., Gazolla, A. P., Pedroso, R. C. N., Pimenta, L. P., de Oliveira, P. F., Tavares, D. C., Silva, M. L. A., Cunha, W. R., Pietro, R. C. L. R., Januario, A. H., Pauletti, P. M., Sales, J. F. \& Silva, F. G. (2016). Antifungal and cytotoxicity activities of Anacardium othonianum extract. Journal of Medicinal Plants Research, 10(29), 450-456. doi: 10.5897/JMPR2016.6115

Gazolla, A. P., Curado, F. M. L. M. J., Pedroso, R. C. N., Filho, L. C. K., Sales, J. F., Rosa, M., Costa, A. C., Pauletti, P. M., Januario, A. H. \& Silva, F. G. (2017). The influence of light quality on phenolic acid and biflavonoid production in Anacardium othonianum Rizz. seedlings grown in vitro. Australian Journal of Crop Science, 11(5), 528-534. doi: 10.21475/ajcs.17.11.05.p314

Ghorbani, M. \& Farhoudi, R. (2018). Leishmaniasis in humans: drug or vaccine therapy? Drug Design, Development and Therapy, 2018(12), 2540. doi: 10.2147/DDDT.S146521

Gimenez, V. M. M., Alvarenga, T. A., Groppo, M., Silva, M. L. A., Cunha, W. R., Januario, A. H., Smilkstein, M. J., Riscoe, M. K. \& Pauletti, P. M. (2019). Antiplasmodial evaluation of Anacardium occidentale and alkylphenols. Revista Brasileira de Farmacognosia, 29(1), 36-39. doi: 10.1016/j.bjp.2018.11.003

Hendrickx, S., Caljon, G. \& Maes, L. (2019). Need for sustainable approaches in antileishmanial drug discovery. Parasitology Research, 118, 27432752. doi: 10.1007/s00436-019-06443-2.

Kubo, I., Komatsu, S. \& Ochi, M. (1986). Molluscicides from the cashew Anacardium occidentale and their large-scale isolation. Journal of Agricultural and Food Chemitry, 34(6), 970-973. doi: 10.1021/jf00072a010

Lomonaco, D., Francisco, D. L., Maia, F. J. N., Clemente, C. S., Mota, J. P. F., Costa Junior, J. E. \& Mazzetto, S. E. (2012). Thermal studies of new biodiesel antioxidants synthesized from a natural occurring phenolic lipid. Fuel, 97, 552-559. doi: 10.1016/j.fuel.2012.01.059

Matutino Bastos, T., Mannochio Russo, H., Silvio Moretti, N., Schenkman, S., Marcourt, L., Gupta, M. P., Wolfender, J. L., Ferreira Queiroz, E. \& Botelho Pereira Soares, M. (2019). Chemical Constituents of Anacardium occidentale as inhibitors of Trypanosoma cruzi Sirtuins. Molecules, 24(7), 1299. doi: 10.3390/molecules24071299.

Oliveira, M. S., Morais, S. M., Magalhães, D. V., Batista, W. P., Vieira, I. G., Craveiro, A. A., de Manezes, J. E., Carvalho, A. F. \& de Lima, G. P. (2011). Antioxidant, larvicidal and antiacetylcholinesterase activities of cashew nut shell liquid constituents. Acta Tropica, 117(3), 165-170. doi: 10.1016/j.actatropica.2010.08.003
Souza, P. L. C. \& Silva, M. R., 2015. Quality of granola prepared with dried caju-do-cerrado (Anacardium othonianum Rizz) and baru almonds (Dipteryx alata Vog). Journal of Food Science and Technology, 52, 1712-1717. doi: 10.1007/s13197-013-1134-4

WHO (2020). Leishmaniasis fact sheet. Avaible in: https://www.who.int/news-room/fact-sheets/detail/leishmaniasis

\section{License: Creative Commons CC BY 4.0}

This article was published with open access for distribution under the terms of the Creative Commons Attribution License, which allows unrestricted use, distribution, and reproduction in any medium, provided the original work is properly cited. 